\title{
DETERMINAN NILAI PERUSAHAAN PADA PERUSAHAAN MAKANAN DAN MINUMAN DI BURSA EFEK INDONESIA
}

Sylma Izzati Maldina

\author{
Universitas Pembangunan Nasional "Veteran" Jakarta \\ sylma.im@upnvj.ac.id \\ Jubaedah Nawir \\ Universitas Pembangunan Nasional "Veteran" Jakarta \\ jubaedah@upnvj.ac.id \\ Dahlia Br Pinem \\ Universitas Pembangunan Nasional "Veteran" Jakarta \\ dahlia.pinem@upnvj.ac.id
}

\begin{abstract}
By using a quantitative study, this research aims to determine the effect of Liquidity, Leverage, and Profitability on Firm Value. This research used food and beverage companies on the Indonesia Stock Exchange for the 2016-2019 period as a population and all companies listed in same sector with an observation period of four years as a sample because the sample technique used is a saturated sample, so that all 30 companies are obtained for the 2016-2019 period as a sample data. This research is tested through E-Views 11 using Panel Data Regression Analysis Method with a significance level of 5\%. The results of this study are there is no significant effect between Liquidity and Firm Value, there is a significant positive effect between Leverage and Firm Value, there is a significant positive effect between Profitability and Firm Value.
\end{abstract}

Keywords: Firm Value; Leverage; Liquidity; and Profitability

\section{PENDAHULUAN}

Organisasi saat mengembangkan usahanya dan menjaga keberlanjutan di masa depan, perlu memperoleh laba untuk menjaga keseimbangan keuangan agar dapat berjalan dengan baik dan maksimal. Untuk mencapai semua itu, perusahaan perlu melihat peluang-peluang yang ada untuk mengembangkan usahanya. Peluang menjanjikan di sektor makanan dan minuman, membuat banyak pemegang saham tertarik berinvestasi karena pada sektor ini, merupakan sektor yang tetap bertahan dikala ekonomi sedang mengalami kondisi yang buruk.

Sebelum melakukan investasi, pemegang saham pasti menganalisis terlebih dahulu apakah adanya prospek yang baik di perusahaan yang ingin diinvestasikan dengan melihat nilai perusahaannya. Persepsi pemegang saham dapat berubah sejalan dengan tinggi rendahnya nilai perusahaan yang menggambarkan kinerja dan 
kondisi keuangan perusahaan (Sukarya \& Baskara, 2019). Analisis prospek perusahaan dilakukan dengan melihat nilai perusahaannya yang dapat dipengaruhi oleh beberapa faktor yakni likuiditas, leverage, dan profitabilitas.

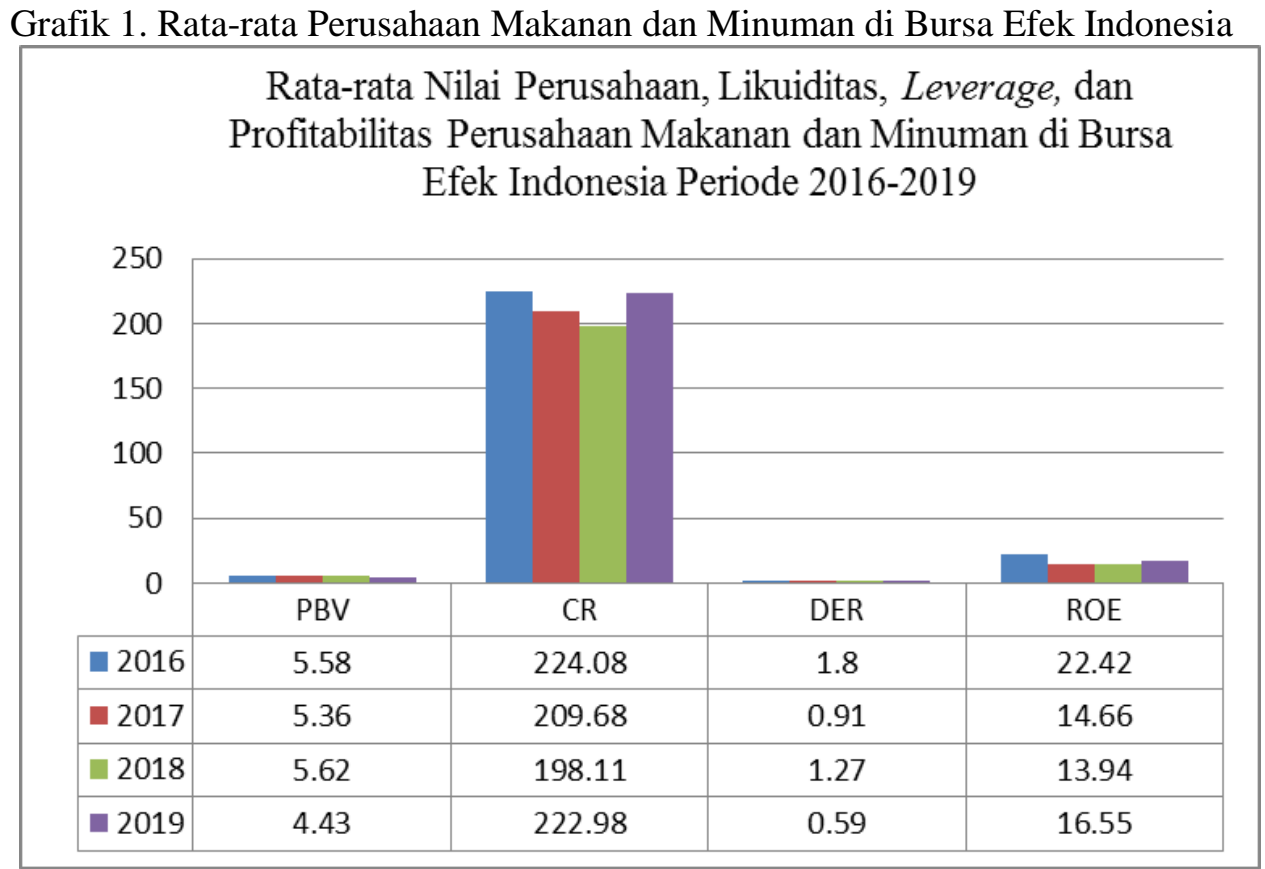

Sumber: idx.co.id

Grafik diatas menunjukkan adanya fluktuasi rata-rata setiap tahunnya, dimana fluktuasi nilai perusahaan cenderung mengalami penurunan. Pada tahun 2017-2018 terjadi penurunan nilai perusahaan yang searah dengan penurunan likuiditas, leverage dan profitabilitas di tahun yang sama ada sekitar 30 persen perusahaan makanan dan minuman yang mengalami penurunan, jika terus-menerus terjadi penurunan maka sinyal yang akan ditangkap pemegang saham ialah perusahaan tidak bisa memberikan keuntungan yang diharapkan serta akan mempertimbangkan kembali keputusan investasinya. Pada tahun 2019, terjadi penurunan nilai perusahaan namun bertolak belakang dengan likuiditas dan profitabilitas yang mengalami kenaikan.

Fenomena kenaikan likuiditas pada tahun 2019, dapat mengindikasikan adanya kepercayaan pemegang saham dalam mempercayakan dana investasinya di perusahaan tersebut karena risiko kegagalan perusahaan dalam memenuhi kewajiban akan semakin rendah. Namun, fenomena ini bertentangan karena nilai perusahaan pada tahun 2016-2019 mengalami fluktuasi dan cenderung terjadi penurunan. Nilai 
perusahaan yang turun tahun 2017 diiringi oleh turunnya rata-rata likuiditas pada tahun 2017. Dengan penjabaran fenomena diatas, bertolak belakang dengan hasil penelitian oleh (Firda dkk., 2021) yang menghasilkan likuiditas dengan nilai perusahaan tidak memiliki pengaruh satu sama lain. Namun, sejalan dengan penelitian sebelumnya mengenai berpengaruhnya likuiditas terhadap nilai perusahaan (Nurhayati dkk., 2019), (Jihadi dkk., 2021) dan (Sukarya \& Baskara, 2019).

Atas dasar grafik 1. terdapat fluktuasi rata-rata leverage yang terjadi setiap tahunnya. Pada tahun 2017 sekitar 46 persen perusahaan yang mengalami penurunan, sedangkan pada tahun 2019 sekitar 60 persen perusahaan kembali mengalami penurunan. Pada hasil penelitian oleh (Glory dkk., 2020) (Pioh dkk., 2018) (Sutama \& Lisa, 2018) (Yanti \& Darmayanti, 2019), mengemukakan, adanya pengaruh leverage dengan nilai perusahaan. Dibuktikan pada angka rata-rata nilai perusahaan makanan dan minuman pada periode 2016-2019 karena tingginya leverage dapat mencerminkan adanya peningkatan nilai perusahaan yang disebabkan oleh adanya asumsi pemegang saham atas peluang menjanjikan yang dimiliki oleh perusahaan. Dengan memperoleh pinjaman, maka kreditur percaya bahwa perusahaan sanggup memenuhi kewajibannya tepat waktu sesuai dengan ketentuan yang sudah disepakati (Glory dkk., 2020). Namun fenomena ini bertentangan dari hasil penelitian oleh (Aeni \& Asyik, 2019) dan (Puspitasari \& Santoso, 2020) dengan penelitiannya yang ditemukan adanya pengaruh negatif leverage dengan nilai perusahaan.

Pergerakan laba dapat dijadikan faktor lain yang melandaskan pengaruh nilai perusahaan. Profitabilitas dijelaskan sebagai kapabilitas setiap perusahaan ketika menghasilkan laba yang dihasilkan dari keefektifannya dalam mengelola sumber daya, hal ini dapat menggambarkan keberhasilan manajemen secara keseluruhan (Sutama \& Lisa, 2018). Profitabilitas yang tinggi, dapat menarik pemegang saham untuk menanamkan modalnya karena dianggap memiliki sinyal bahwa perusahaan mampu memberi keuntungan yang diharapkan. Berdasar pada grafik diatas, terjadi penurunan profitabilitas secara terus menerus pada tahun 2017 sampai 2018 terdapat sekitar 50 persen perusahaan makanan dan minuman yang mengalami penurunan profitabilitas, penurunan profitabilitas secara terus menerus, akan memberikan persepsi bahwa tidak ada peluang yang menjanjikan kedepannya. Menurunnya profitabilitas sejalan dengan menurunnya nilai perusahaan pada tahun 2017. Fenomena selaras dengan hasil penelitian oleh (Nurhayati dkk., 2019), (Firda dkk., 2021)) dan (Sutama \& Lisa, 2018) ditemukan hasil profitabilitas dan nilai perusahaan memiliki pengaruh positif signifikan.

Mengacu pada pemaparan latar belakang, dapat diambil kesimpulan bahwa adanya faktor-faktor yang mempengaruhi pergerakan nilai perusahaan dimana pada teori menjelaskan jika terdapat kenaikan likuiditas, leverage dan profitabilitas maka akan memberi pengaruh pada pergerakan nilai perusahaan.

Sehingga, dari penjabaran fenomena diatas, penelitian ini terdapat rumusan 
masalah yakni: Apakah Likuiditas, Leverage dan Profitabilitas berpengaruh positif terhadap Nilai Perusahaan. Penelitian ini memiliki tujuan pencapaian ialah untuk mengetahui dan menganalisis masing-masing faktor seperti Likuiditas, Leverage dan Profitabilitas atas pengaruhnya terhadap Nilai Perusahaan sub-sektor makanan dan minuman di BEI.

\section{KAJIAN PUSTAKA DAN PENGEMBANGAN HIPOTESIS}

\section{Teori Sinyal}

Sinyal ialah tindakan manajemen perusahaan dalam memberikan tanda kepada pemegang saham bagaimana manajemen perusahaan melihat prospek perusahaannya (Brigham \& Houston, 2017, p. 478). Sinyal yang dikirimkan oleh perusahaan kepada pemegang saham dilakukan dengan pengungkapan informasi internal perusahaan untuk mengurangi ketidakpastian dan asumsi tentang prospek perusahaan serta untuk meningkatkan nilai perusahaan. Teori sinyal menjelaskan sinyal-sinyal yang diberikan oleh internal perusahaan untuk pengguna laporan keuangan, khususnya untuk setiap pemegang saham yang ingin melakukan investasi (Sinaga dkk., 2020). Sinyal positif yang diberikan oleh perusahaan dengan adanya pengungkapan informasi perusahaan seperti penyajian informasi finansial maupun non-finansial yang dapat menjadi pertimbangan pemegang saham dalam menentukan keputusan investasinya karena jika perusahaan memberikan sinyal adanya peningkatan kinerja keuangan, maka pemegang saham yakin akan prospek keberlanjutan yang baik. Namun sebaliknya, jika penurunan kinerja keuangan perusahaan terjadi, maka pemegang saham perlu mempertimbangkan lagi keputusan investasinya apakah perusahaan tersebut dapat bertahan dan memberikan keuntungan atas investasinya atau tidak.

\section{Nilai Perusahaan}

Perspektif pemegang saham tentang nilai perusahaan ialah tingkat kapabilitas suatu perusahaan dalam pengelolaan sumber daya untuk memaksimalkan tujuan utama perusahaan, yakni keuntungan perusahaan yang dicerminkan dengan harga saham perusahaan tersebut (Purwanti, 2020). Kemakmuran dan kepercayaan pemegang saham atas prospek keberlanjutan perusahaan yang menjanjikan akan menyebabkan nilai perusahaan menjadi naik sehingga membuat pemegang saham lainnya tertarik dan mempercayakan dana investasinya pada organisasi tersebut. Harga saham merepresentasikan nilai perusahaan karena dengan adanya pergerakan harga saham perusahaan dapat mengindikasikan sinyal kepada pemegang saham tentang kinerja perusahaan tersebut (Setyowati dkk., 2020). Menurut (Samsul 2015 dalam Dahar dkk, 2020) faktor nilai perusahaan dapat direpresentasikan oleh dua faktor utama yakni faktor mikro ekonomi diantaranya adalah rasio keuangan perusahaan dan makro ekonomi diantaranya inflasi, tingkat bunga, pajak, kebijakan 
pemerintah, kurs valuta asing, siklus ekonomi, peredaran uang dan ekonomi internasional.

\section{Laporan Keuangan}

Posisi keuangan yang dibuat secara struktur yang menunjukkan kinerja keuangan perusahaan, adalah laporan keuangan. Analisis laporan keuangan yang disajikan pada khalayak dapat berguna sebagai informasi penilaian kondisi keuangan perusahaan (Rochman \& Pawenary, 2020). Laporan keuangan disajikan dengan informasi mengenai pos-pos akuntansi dalam periode tertentu untuk dijadikan referensi dalam pengambilan keputusan manajemen perusahaan. Manfaat laporan keuangan dapat diperoleh melalui analisis kinerja keuangan yang dituangkan dari perbandingan antara pos-pos keuangan dan rasio keuangan serta dapat melihat kondisi keadaan keuangan pada waktu dan periode tertentu (Kasmir, 2017, p. 66). Dalam praktiknya laporan keuangan terdiri dari berbagai macam jenis ialah neraca, laporan catatan atas laporan, laporan laba rugi, laporan perubahan kas, serta laporan perubahan ekuitas (Kasmir, 2017).

\section{Rasio Keuangan}

Dalam neraca dan laporan laba rugi, terdapat angka-angka yang menunjukan rasio keuangan yang fungsinya untuk menghubungkan dua angka akuntansi untuk dibandingkan dengan angka-angka lainnya. Perbandingan antar angka akuntansi ini, dilakukan dengan akun-akun yang tersedia di laporan keuangan. Dalam Kasmir (2017, hal. 94), penggolongan rasio keuangan yang secara umum telah diketahui untuk membandingkan angka-angka sesuai dengan rasio keuangan, yakni rasio neraca, rasio laporan laba rugi, dan rasio antar laporan.

Dalam menilai kinerja manajemen yang beragam, maka terdapat beberapa jenis rasio keuangan yang disesuaikan dengan kondisi dan kebutuhan perusahaan. Rasio keuangan yang digunakan diantaranya rasio likuiditas, rasio solvabilitas, rasio aktivitas, rasio profitabilitas, rasio pertumbuhan, dan rasio penilaian.

\section{Likuiditas dan Nilai Perusahaan}

Tingginya likuiditas memproyeksikan kekuatan perusahaan dalam pemenuhan kewajiban dari aset yang dimiliki perusahaan sehingga akan terjadi peningkatan kepercayaan pihak eksternal akan perusahaan (Ardiansari \& Sukmawardini, 2018). Likuiditas umumnya dipakai untuk menganalisis kemampuan perusahaan dalam membayar kewajibannya dengan tepat waktu. Prospek yang baik perusahaan dapat terlihat dari ketepatan waktu perusahaan dalam membayar (Setyowati dkk., 2020). Likuiditas yang baik merupakan tanda bagi para pemegang saham terkait kemampuan perusahaan dalam membiayai operasional perusahaan dan investasi perusahaan sehingga jika perusahaan mampu dan memiliki likuiditas yang tinggi maka akan selaras dengan kenaikan nilai perusahaan sebab permintaan saham perusahaan di bursa akan meningkat (Firda dkk., 2021). Tingginya rasio likuiditas 
dapat menggambarkan likuidnya perusahaan sehingga menimbulkan asumsi perusahaan memiliki kinerja yang memuaskan sehingga dapat selalu membayar hutangnya tepat waktu dan masih mampu untuk membayarkan hutang-hutang yang dimiliki.

\section{Leverage dan Nilai Perusahaan}

Leverage merupakan penggambaran perusahaan dalam mengelola hutangnya untuk membiayai proses operasional perusahaan. Pengukuran keberhasilan perusahaan untuk menjamin hutangnya dengan aset yang ada, tercermin dalam rasio leverage. Pergerakan nilai leverage dapat disebabkan oleh banyaknya penggunaan hutang oleh perusahaan yang bertujuan untuk mengekspansi perusahaan, adanya inovasi baru dan juga untuk biaya operasional perusahaan yang tidak dicukupi dengan modal perusahaan. Leverage yang tinggi juga dapat meningkatkan kepercayaan pemegang saham karena dengan diberikannya hutang kepada perusahaan, kreditur menganggap perusahaan dimasa depan akan memiliki prospek yang menjanjikan sehingga mampu membayar hutangnya nanti saat jatuh tempo. Hal ini dapat berdampak kepada meningkatnya nilai perusahaan (Sinaga dkk., 2020).

\section{Profitabilitas dan Nilai Perusahaan}

Profitabilitas merupakan indikator penilaian untuk melihat prospek perusahaan bagi calon pemegang saham dengan menganalisis seberapa besar perusahaan dapat menghasilkan laba (Puspitasari \& Santoso, 2020). Tingginya profitabilitas maka semakin banyak distribusi pendapatan untuk pemegang saham dan hal ini akan menyebabkan nilai perusahaan lebih tinggi. Dalam memberikan sinyal profitabilitas, perusahaan akan memperlihatkan kesuksesan kinerja perusahaan yang dituangkan oleh laporan keuangan sehingga pemegang saham dapat melihat laba yang berhasil diperoleh oleh perusahaan dari berbagai bidang yang dimiliki oleh perusahaan, hal ini dapat mencerminkan keefektifan perusahaan dan keberhasilan manajemen perusahaan (Ardiansari \& Sukmawardini, 2018). Perusahaan dalam memaksimalkan laba, pemanfaatan sumber daya secara maksimal sangat penting dilakukan agar perusahaan dapat bekerja maksimal namun tetap efektif dan efisien. Laba yang besar merupakan salah satu ukuran dan tanda bahwa perusahaan tersebut berhasil meraih profitabilitas yang tinggi dan memiliki prospek baik. Pemegang saham menggunakan rasio profitabilitas untuk mengukur apakah suatu perusahaan memiliki prospek yang bagus dilihat dari analisis pertumbuhan laba perusahaan. Tingginya profitabilitas yang diperoleh perusahaan, akan sejalan dengan kenaikan harga saham karena dianggap memiliki kinerja yang memuaskan dan akan memakmurkan pemegang saham atas perolehan yang didapat dari dana yang diinvestasikannya. 


\section{Model Penelitian}

Gambar 1. Model Penelitian

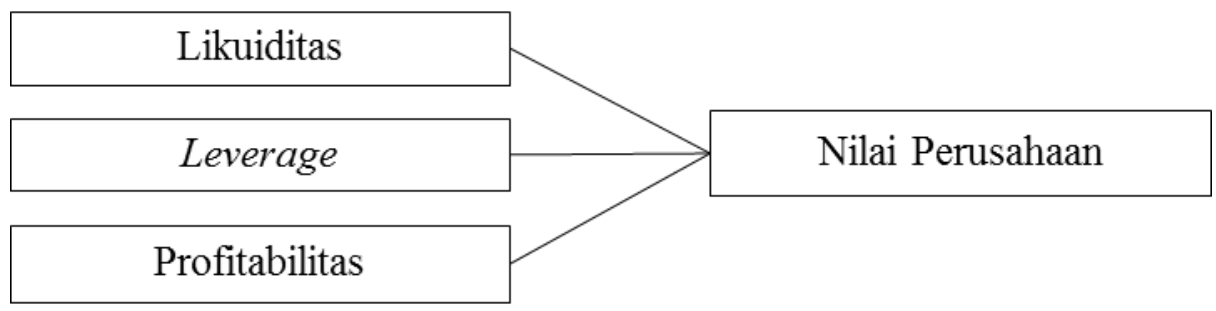

\section{Hipotesis}

Didasarkan pada penjabaran perumusan masalah, landasan teori dan model peneltian sebelumnya, hipotesis yang diajukan dari penelitian ini ialah:

$\mathrm{H}_{1}$ : Likuiditas memiliki pengaruh positif signifikan terhadap Nilai Perusahaan.

$\mathrm{H}_{2}$ : Leverage memiliki pengaruh positif signifikan terhadap Nilai Perusahaan.

$\mathrm{H}_{3}$ : Profitabilitas memiliki pengaruh positif signifikan terhadap Nilai Perusahaan

\section{METODE PENELITIAN}

\section{Populasi dan Sampel}

Populasi dan sampel pada penelitian berjumlah 30 perusahaan makanan dan minuman di Bursa Efek Indonesia periode 2016-2019, dengan pengambilan sampel dengan cara sensus (sampel jenuh) sehingga total data yang digunakan ialah 120 data sampel.

\section{Pengukuran Variabel}

Variabel Dependen (Y)

Nilai perusahaan memiliki arti perspektif pemegang saham atas tingkat keberhasilan suatu perusahaan dalam memaksimalkan pemanfaatan sumber daya untuk memperoleh keuntungan yang dicerminkan dengan harga saham perusahaan tersebut. Diukur menggunakan rasio PBV yakni untuk menunjukkan besaran harga nilai buku saham yang diberikan pasar untuk suatu perusahaan.

$$
\mathrm{PBV}=\frac{\text { Harga per Lembar Saham }}{\text { Nilai Buku per Lembar Saham }}
$$

\section{Variabel Independen $(X)$}

a. Likuiditas

Likuiditas memiliki arti penggambaran keberhasilan perusahaan untuk menyanggupi kewajiban jangka pendeknya sesuai tenggat waktu yang diberikan. Likuiditas diukur menggunakan Current Ratio (CR). 
b. Leverage

$$
\mathrm{CR}=\frac{\text { Aktiva Lancar (Current Assets })}{\text { Hutang Lancar (Current Liabilities) }}
$$

Leverage menggambarkan pendanaan yang diperoleh untuk membiayai operasional perusahaan. Pengukuran Leverage ialah menggunakan Debt Equity Ratio (DER).

$$
\mathrm{DER}=\frac{\text { Total } D_{e b t}}{\text { Equity }}
$$

c. Profitabilitas

Profitabilitas menunjukkan kapabilitas suatu perusahaan dalam pengelolaan sumber daya untuk memperoleh laba yang diharapkan. Pengukuran rasio menggunakan Return on Equity (ROE).

$$
\mathrm{ROE}=\frac{\text { Earning After Interest and Tax }}{\text { Equity }}
$$

\section{Teknik Pengumpulan Data}

Penelitian yang dilakukan tergolong penelitian dengan analisis kualitatif dan jenis data yang digunakan ialah data sekunder. Data penelitian bersumber dari studi kepustakaan dengan mengkaji literatur dan dokumentasi yakni mengumpulkan data secara online melalui jurnal ilmiah, buku dan portal berita serta data pada laman resmi BEI dan perusahaan terkait.

\section{Teknik Analisis Data}

Data penelitian dianalisis menggunakan metode analisis regresi data panel, dibantu dengan program komputer Microsoft Office Excel 2010 serta program Eviews 11. Berikut model persamaan regresi data panel pada penelitian:

$$
Y_{i t}=\beta_{0}+\beta_{1} X_{1 i t}+\beta_{2} X_{2 i t}+\beta_{3} X_{3 i t}+\mu_{i t}
$$

Keterangan:

$\mathrm{Y} \quad=$ Nilai Perusahaan

$\beta \quad=$ Konstanta

$\beta_{1}, \beta_{2}, \beta_{3}=$ Koefisien

$\mathrm{X}_{1} \quad=$ Likuiditas

$\mathrm{X}_{2} \quad=$ Leverage

$\mathrm{X}_{3} \quad=$ Profitabilitas

$\mathrm{i} \quad=$ Perusahaan Makanan dan Minuman

$\mathrm{t} \quad=$ Periode Waktu

$\mu \quad=$ Error Term

\section{Uji Hipotesis}

Tujuan dilakukannya uji hipotesis guna membuktikan hipotesis yang sudah dirumuskan terlebih dahulu. Jawaban hasil pengujian hipotesis dapat dibuktikan 
melalui pengaplikasian Uji Parsial (uji t) dan Uji Koefisien Determinasi $\left(R^{2}\right)$.

\section{HASIL DAN PEMBAHASAN}

\section{Deskripsi Objek Penelitian \\ Statistik Deskriptif}

Berikut hasil statistik deskriptif dari tiap-tiap variabel penelitian yang diolah menggunakan bantuan program E-Views 11 .

Tabel 1. Hasil Statistik Deskriptif

\begin{tabular}{lccll}
\hline \hline & PBV & CR & DER & ROE \\
\hline \hline Mean & 4.696917 & 161.7233 & 0.793833 & 9.696167 \\
Median & 1565000 & 117.2350 & 0.595000 & 6.510000 \\
Maximum & 67.03000 & 863.7800 & 10.70000 & 128.1100 \\
Minimum & -2.830000 & 3.410000 & -11.00000 & -24.87000 \\
Std. Dev. & 10.24918 & 181.2179 & 1.768731 & 30.81668 \\
Observations 120 & 120 & 120 & 120 \\
\hline \hline
\end{tabular}

Sumber: E-Views 11 (data diolah)

Didasarkan hasil pengujian statistik pada Tabel 1, interpretasi yang diperoleh ialah:

a. Variabel Nilai Perusahaan

Rata-rata Nilai Perusahaan dari periode 2016-2019 yang tercatat sebanyak 30 menunjukan angka sebesar 4.696917. Selain itu pada nilai tertinggi sebesar 67.03000 berasal dari perusahaan Prima Cakrawala Abadi Tbk. Di tahun 2018. Nilai terendah di tahun 2019 ialah sebesar -2.830000 pada perusahaan Magna Investama Mandiri Tbk. Pada standar deviasi Nilai Perusahaan sebesar 10.24918, rendahnya nilai rata-rata dari nilai standar deviasi menandakan adanya kesenjangan nilai tertinggi dan terendah pada data penelitian dan data yang digunakan heterogen.

b. Variabel Likuiditas

Nilai rata-rata Likuiditas dari 30 perusahaan periode pengamatan 2016-2019 sebesar 193.8406. Selain itu pada nilai tertinggi sebesar 863.7800 berasal dari perusahaan Delta Djakarta Tbk tahun 2017. Lalu pada nilai terendah berada di angka 3.410000 pada perusahaan Multi Bintang Indonesia Tbk tahun 2019. Pada standar deviasi Likuiditas sebesar 181.2179. 
c. Variabel Leverage

Nilai rata-rata Leverage dari 30 perusahaan periode pengamatan 2016-2019 sebesar 0.793833 . Selain itu pada nilai tertinggi sebesar 10.70000 berasal dari perusahaan Siantar Top Tbk tahun 2016. Lalu pada nilai terendah sebesar 11.00000 pada perusahaan Multi Bintang Indonesia Tbk tahun 2019. Pada standar deviasi Leverage sebesar 181.2179.

d. Variabel Profitabilitas

Nilai rata-rata Profitabilitas dari 30 perusahaan periode pengamatan 2016-2019 sebesar 9.696167. Selain Multi Bintang Indonesia Tbk di tahun 2017 memperoleh nilai tertinggi sebesar 128.1100. Lalu pada nilai terendah dari Tiga Pilar Sejahtera Food Tbk sebesar -24.87000 di tahun 2018. Pada standar deviasi Profitabilitas sebesar 30.81668.

\section{Uji Hipotesis dan Analisis Data} Uji Chow (F Restricted)

Tabel 2. Hasil Uji Chow

\begin{tabular}{lcll}
\hline \hline Effects Test & Statistic & d.f. & Prob. \\
Cross-section F & 3.858094 & $(29,87)$ & 0.0000 \\
Cross-section Chi-square & 99.218069 & 29 & 0.0000 \\
\hline
\end{tabular}

Sumber: E-Views 11 (data diolah)

Mengacu hasil pengujian $F$ Restricted. Pada Cross-section Chi-Square menunjukkan angka probabilitas sebesar 0.0000 lebih rendah dari 0.05. Sehingga pendekatan yang akan digunakan ialah Fixed Effect Model. Selanjutnya dilakukan Uji Haussman untuk menetapkan pendekatan yang paling akurat digunakan pada penelitian ini.

\section{Uji Haussman}

Tabel 3. Hasil Uji Haussman

\begin{tabular}{llll}
\hline \hline Test Summary & Chi-Sq. Statistic & \multicolumn{2}{l}{ Chi-Sq. d.f. Prob. } \\
\hline Cross-section random & 15.131423 & 3 & 0.0017 \\
\hline \hline
\end{tabular}

Sumber: E-Views 11 (data diolah)

Atas dasar hasil pengujian haussman. Nilai Cross-section Random menunjukkan angka probabilitas sebesar 0.0017 lebih rendah dari 0.05. Maka hasil uji menyatakan pendekatan digunakan ialah Fixed Effect Model.

\section{Fixed Effect Model (FEM)}

Atas dasar kedua pengaplikasian kedua uji yakni Uji Chow (Uji F Restricted) dan Uji Haussman, didapatkan bahwa model pengukuran yang dipilih untuk 
diaplikasikan pada penelitian ini ialah model Fixed Effect (FEM). Berikut hasil pengolahan data menggunakan model Fixed Effect dan pengaruh tiap-tiap variabel pada penelitian ini.

Tabel 4. Fixed Effect Model

\begin{tabular}{lllll}
\hline Variable & Coefficient & Std. Error & t-Statistic & Prob. \\
\hline $\mathrm{C}$ & 1.937452 & 1.130718 & 1.713471 & 0.0893 \\
$\mathrm{CR}$ & 0.001209 & 0.003264 & 0.370352 & 0.7118 \\
$\mathrm{DER}$ & 1.253261 & 0.472049 & 2.654939 & 0.0090 \\
ROE & 0.157824 & 0.027278 & 5.785749 & 0.0000 \\
\hline \hline
\end{tabular}

Sumber: E-Views 11 (data diolah)

Dari hasil pengolahan data yang menggunakan Model Fixed Effect, didapatkan regresi data panel yang dikemukakan sebagai berikut: $\mathrm{PBV}=1.937452+$ $0.001209(\mathrm{CR})+1.253261(\mathrm{DER})+0.157824(\mathrm{ROE})$

a. Pada tabel 9, dapat disimpulkan hasil uji regresi untuk variabel Nilai Perusahaan memiliki nilai konstanta sebesar 1.937452. Hal ini memiliki arti jika masingmasing variabel Likuiditas, Leverage, dan Profitabilitas tidak berubah/konstan, maka Nilai Perusahaan sebesar 1.937452.

b. Variabel Likuiditas (CR) berdasar tabel diatas menunjukkan 0.001209, dengan arti setiap kenaikan CR senilai satu satuan yang diasumsikan nilai koefisien variabel lain tidak berubah atau konstan maka terjadi kenaikan Nilai Perusahaan sebesar 0.001209. Hal ini menunjukkan hubungan Likuiditas dengan Nilai Perusahaan memiliki hubungan positif atau jika terdapat kenaikan Likuiditas maka Nilai Perusahaan akan mengalami kenaikan.

c. Variabel Leverage (DER) ialah sebesar 1.253261, jika terjadi kenaikan DER senilai satu satuan yang diasumsikan nilai koefisien variabel selain DER tidak berubah atau konstan maka Nilai Perusahaan akan mengalami kenaikan yakni 1.253261. Hal ini menunjukkan hubungan Leverage dengan Nilai Perusahaan memiliki hubungan positif atau jika terdapat kenaikan Leverage maka Nilai Perusahaan akan mengalami kenaikan.

d. Variabel Profitabilitas (ROE) sebesar 0.157824, dapat menunjukkan kenaikan ROE senilai satu satuan yang diasumsikan nilai koefisien variabel selain ROE tidak berubah atau konstan maka terdapat perubahan Nilai Perusahaan yang naik sebesar 0.157824. Hal ini menunjukkan terdapat pengaruh yang positif antara Profitabilitas dan Nilai Perusahaan atau jika terdapat kenaikan Profitabilitas maka Nilai Perusahaan akan mengalami kenaikan.

\section{Uji Parsial (Uji t)}

Metode Uji Parsial (uji t) dimaksudkan guna mengambil keputusan hipotesis yang sudah dibuat sebelumnya yang diukur menggunakan perbandingan nilai $t_{\text {hitung }}$ 
dan $\mathrm{t}_{\text {tabel }}$. Pengukuran nilai $\mathrm{t}_{\text {tabel }}$ terlihat dalam tabel statistik dengan 0.05 sebagai nilai signifikansi melalui perhitungan derajat df (degrees of freedom). Dalam penelitian ini dapat dihitung nilai df adalah sebagai berikut:

df = jumlah observasi $(n)-$ jumlah variabel independen $(k)$

$\mathrm{df}=120-4=116$

Nilai $\mathrm{t}_{\text {tabel }}$ yang sesuai dengan menggunakan tabel statistik dan nilai signifikansi sebesar 0.05 adalah 1.98063. Berikut hasil Uji Parsial (Uji t) yang dilakukan menggunakan program E-Views 11:

Tabel 5. Hasil Uji t

\begin{tabular}{lllll}
\hline \hline Variable & Coefficient & Std. Error & t-Statistic & Prob. \\
\hline C & 1.937452 & 1.130718 & 1.713471 & 0.0893 \\
LIKUIDITAS & 0.001209 & 0.003264 & 0.370352 & 0.7118 \\
LEVERAGE & 1.253261 & 0.472049 & 2.654939 & 0.0090 \\
PROFITABILITAS & 0.157824 & 0.027278 & 5.785749 & 0.0000 \\
\hline \hline
\end{tabular}

Sumber: E-Views 11 (data diolah)

Berdasar atas hasil Uji Parsial (Uji t) di Tabel 5, dapat dijabarkan yaitu sebagai berikut:

a. Pengaruh Likuiditas terhadap Nilai Perusahaan

Mengacu hasil pada Tabel 5, nilai $\mathrm{t}_{\text {statis }}$ untuk variabel Likuiditas (CR) menunjukkan perbandingan $0.370352<1.98063$. Sementara pada nilai probabilitas, yakni $0.7118>0.05$. Sehingga konklusi yang diperoleh ialah $\mathrm{H}_{0}$ diterima dan $\mathrm{H}_{\mathrm{a}}$ ditolak atau tidak adanya pengaruh yang signifikan dari variabel Likuiditas terhadap Nilai Perusahaan.

b. Pengaruh Leverage terhadap Nilai Perusahaan

Atas dasar pengolahan data Uji Parsial, terlihat nilai $\mathrm{t}_{\text {statis }}$ untuk variabel Leverage (DER) menunjukkan perbandingan $2.654939>1.98063$. Sementara pada nilai probabilitas, sebesar $0.0090<0.05$. Sehingga diperoleh jawaban atas dugaan sementara ialah $\mathrm{H}_{0}$ tolak dan $\mathrm{H}_{\mathrm{a}}$ diterima atau variabel Leverage berpengaruh signifikan terhadap Nilai Perusahaan.

c. Pengaruh Profitabilitas terhadap Nilai Perusahaan

Mengacu dari pengolahan data Uji Parsial, terlihat nilai $t_{\text {statis }}$ untuk variabel Profitabilitas (ROE) ialah sebesar $5.785749>1.98063$. Sementara pada nilai probabilitas, yaitu sebesar $0.0000<0.05$. Sehingga konklusi yang didapatkan ialah $\mathrm{H}_{0}$ tolak dan $\mathrm{H}_{\mathrm{a}}$ diterima atau variabel Profitabilitas berpengaruh signifikan terhadap Nilai Perusahaan. 


\section{Uji Koefisien Determinasi $\left(R^{2}\right)$}

Tabel 6. Uji Koefisien Determinasi

\begin{tabular}{ll}
\hline \hline R-squared & 0.246295 \\
Adjusted R-squared & 0.226803 \\
S.E. of regression & 9.012270 \\
Sum squared resid & 9421.637 \\
Log likelihood & -432.0690 \\
F-statistic & 12.63546 \\
Prob(F-statistic) & 0.000000 \\
\hline \hline
\end{tabular}

Sumber: E-Views 11 (data diolah)

Mengacu pada Tabel 6, menghasilkan nilai Adjusted $R$-Squared yang menunjukkan angka 0.226803. Sehingga simpulan yang didapat ialah variabel terikat (Nilai Perusahaan) mampu menjelaskan pengaruhnya oleh variabel bebas (Likuiditas, Leverage, Profitabilitas) dan sisanya pada 77.62\% (100\% - 22.38\%) dijelaskan pengaruhnya oleh variabel lain yang lebih mendominasi pada nilai perusahaan namun tidak digunakan pada penelitian ini contohnya pengaruh dari makro ekonomi.

\section{Pembahasan}

\section{Pengaruh Likuiditas Terhadap Nilai Perusahaan}

Atas dasar uji hipotesis dengan program E-Views 11, menghasilkan variabel Likuiditas diukur oleh CR tidak memiliki pengaruh terhadap Nilai Perusahaan yang diukur oleh PBV sehingga adanya penolakan hipotesis $\left(\mathrm{H}_{1}\right)$ yang telah dirumuskan.

Berdasar kepada teori sinyal, dimana perusahaan memberikan informasi berupa sinyal kepada pemegang saham, yakni informasi rasio likuiditas pada laporan keuangan perusahaan, dapat diindikasikan menjadi sinyal yang positif karena rasio ini memperlihatkan perusahaan dalam kemampuannya menyanggupi kewajiban jangka pendeknya dengan tepat waktu, namun penelitian ini tidak menunjukan hasil yang searah dengan teori dan hipotesis yang telah dijabarkan sebelumnya. Maka dapat diartikan bahwa pemegang saham tidak melihat likuiditas sebagai acuan utama untuk mempertimbangkan keputusan investasinya di perusahaan makanan dan minuman, hal ini disebabkan indikator likuiditas dapat meningkat karena adanya aset yang berlebih seperti terdapat piutang yang tidak bisa ditagih, idle cash, serta persediaan yang tidak digunakan secara maksimal untuk kegiatan operasional perusahaan maupun mengembangkan perusahaannya sehingga terjadi penumpukan. 


\section{Pengaruh Leverage Terhadap Nilai Perusahaan}

Mengacu dari hasil uji hipotesis menggunakan E-views 11, memperlihatkan bahwa variabel Leverage yang diukur oleh DER, memiliki pengaruh terhadap Nilai Perusahaan diukur oleh PBV atau hipotesis $\left(\mathrm{H}_{2}\right)$ diterima.

Hasil dari hipotesis, searah dengan teori sinyal dimana perusahaan memberi informasi atau sinyal-sinyal kepada pemegang saham akan kondisi perusahaan saat ini. Tujuan digunakannya hutang perusahaan untuk memperluas perusahaan dan digunakan untuk biaya operasional perusahaan yang tidak dicukupi dengan modal perusahaan selain itu penggunaan hutang dapat memberikan perspektif pemegang saham dalam melihat prospek keberlanjutan perusahaan yang baik karena dengan diberikannya pinjaman modal eksternal, pihak kreditur percaya bahwa perusahaan bisa melunasi kewajibannya tepat waktu dengan kesepakatan perusahaan dan kreditur akan ketentuan dan perjanjiannya, sehingga kepercayaan akan prospek perusahaan ini yang mendasari pemegang saham mau menanamkan dana investasinya di perusahaan sehingga berdampak kepada peningkatan nilai perusahaan.

\section{Pengaruh Profitabilitas Terhadap Nilai Perusahaan}

Atas dasar hasil uji hipotesis menggunakan E-views 11, menunjukkan bahwa variabel Profitabilitas yang diukur dengan ROE memiliki pengaruh terhadap Nilai Perusahaan yang diukur dengan PBV atau hipotesis $\left(\mathrm{H}_{3}\right)$ diterima.

Hasil hipotesis penelitian dengan teori sinyal, yakni perusahaan mempublikasikan informasi internal untuk memberi sinyal akan kondisi perusahaan untuk pemegang saham, dengan adanya pengungkapan informasi seperti tingkat profitabilitas perusahaan maka akan mempengaruhi keputusan pemegang saham dalam menilai perusahaan. Adanya pengaruh variabel profitabilitas terhadap nilai perusahaan karena tingginya nilai profitabilitas akan mengindikasikan kapabilitas perusahaan dalam memberi kemakmuran dan kepercayaan pemegang saham akan perusahaan yang dapat bertahan serta memiliki prospek yang menjanjikan kedepannya. Kepercayaan oleh pemegang saham ini yang akan berdampak atas tingginya nilai perusahaan.

\section{KESIMPULAN}

Atas dasar pengujian hipotesis yang telah dipaparkan, didapat hasil simpulan yakni likuiditas tidak memberikan pengaruh yang signifikan terhadap nilai perusahaan namun, leverage dan profitabilitas memiliki pengaruh positif signifikan terhadap nilai perusahaan. Mengacu pada simpulan diatas, diharapkan penelitian ini dapat menjadi atas dasar pertimbangan manajemen perusahaan untuk menjaga dan mengelola rasio leverage dan profitabilitasnya dengan maksimal dan sebagai 
pertimbangan pemegang saham dalam keputusan investasinya serta untuk peneliti selanjutnya, diharapkan bisa menambah pengaruh faktor makro ekonomi agar penelitian mendapat hasil yang lebih baik. Adanya keterbatasan dalam pelaksanaan penelitian ini yang memungkinkan dapat mempengaruhi hasil yakni penelitian ini menggunakan teknik fundamental dalam menganalisis faktor-faktor dan keterbatasan pencarian literatur pendukung penelitian karena pembatasan COVID19.

\section{DAFTAR PUSTAKA}

Aeni, N. A. M., \& Asyik, N. F. (2019). Pengaruh Profitabilitas, Pertumbuhan Perusahaan, Struktur Modal, Ukuran Perusahaan Terhadap Nilai Perusahaan. Jurnal Ilmu Dan Riset Akuntansi, 8(7).

Ardiansari, A., \& Sukmawardini, D. (2018). The Influence Of Institutional Ownership, Profitability, Liquidity, Dividend Policy, Debt Policy On Firm Value. Management Analysis Journal, 7(2), 211-222.

Brigham, E. F., \& Houston, J. F. (2017). Fundamentals Of Financial Management: Concise, Ninth Edition (Nineth). Cengage Learning.

Dahar, R., Yanti, N. S. P., \& Rahmi, F. (2020). Faktor-Faktor Yang Memengaruhi Harga Saham (Studi Empiris Pada Perusahaan Transportasi Yang Terdaftar Di Bursa Efek Indonesia). Jurnal Ekonomi Dan Bisnis Dharma Andalas, 22(1), 134-145.

Firda, M. B., Novitasari, N. L. G., \& Dewi, N. L. P. S. (2021). Faktor - Faktor Yang Mempengaruhi Nilai Perusahaan Pada Perusahaan Food And Beverage Yang Terdaftar Di Bursa Efek Indonesia. Jurnal Kharisma, 3(1).

Glory, J. B., Yetty, F., \& Triwahyuningtyas, N. (2020). Determinan Nilai Perusahaan Pada Subsektor Makanan Dan Minuman Periode 2016 - 2018. Jurnal Ilmiah Manajemen, 8(3), 239-248.

Jihadi, M., Vilantika, E., Hashemi, S. M., Arifin, Z., Bachtiar, Y., \& Sholichah, F. (2021). The Effect Of Liquidity, Leverage, And Profitability On Firm Value: Empirical Evidence From Indonesia. Journal Of Asian Finance, Economics And Business, 8(3), 423-431. Https://Doi.Org/10.13106/Jafeb.2021.Vol8.No.3.0423

Kasmir. (2017). Pengantar Manajemen Keuangan (2nd Ed.). Prenada Media.

Nurhayati, Ifa, K., \& Paramita, R. W. D. (2019). Pengaruh Return On Equity (Roe), 
Current Ratio (Cr), Dan Debt To Equity Ratio (Der) Terhadap Nilai Perusahaan (Studi Pada Perusahaan Manufaktur Sektor Makanan Dan Minuman Periode 2015 - 2017). Journal Of Accounting, 2(2), 38-41.

Pioh, H. T., Parengkuan, T., \& Jantje, L. S. (2018). Pengaruh Debt To Equity Ratio, Earning Per Share Dan Return On Asset Terhadap Nilai Perusahaan Sub Sector Food And Beverages Di Bursa Efek Indonesia. Jurnal Emba, 6(4), 3018-3027.

Purwanti, T. (2020). The Effect Of Profitability, Capital Structure, Company Size, And Dividend Policy On Company Value On The Indonesia Stock Exchange. International Journal Of Seocology (Science, Education, Economics, Psychology, And Technology, 1(2).

Puspitasari, H. W., \& Santoso, B. H. (2020). Struktur Modal, Profitabilitas, Ukuran Dan Nilai Perusahaan Food And Beverage Di Bei. Jurnal Ilmu, 9(3).

Rochman, \& Pawenary. (2020). Analisis Laporan Keuangan Dalam Menilai Kinerja Keuangan Pt Harum Energy Periode 2014 - 2019. Jurnal Ekonomi Manajemen Sistem Informasi, 2(2). Https://Doi.Org/Https://Doi.Org/10.31933/Jemsi.V2i2

Setyowati, R., Masitoh, E., \& Siddi, P. (2020). Factors Affecting The Value Of Companies In The Food And Beverage Companies Listed On Bei. Journal of Business, Management, And Accounting, 2(1), 147-153.

Sinaga, K. C. K., Miftah, M., \& Wahyuningtyas, N. T. (2020). Analisis Pengaruh Keputusan Investasi Dan Keputusan Pendanaan Terhadap Nilai Perusahaan. Prosiding Biema, 1, 960-972.

Sukarya, I. P., \& Baskara, I. G. K. (2019). Pengaruh Profitabilitas, Leverage, Dan Likuiditas Terhadap Nilai Perusahaan Sub Sektor Food And Beverages. EJurnal Manajemen, 8(1), 7399-7428.

Sutama, D. R., \& Lisa, E. (2018). Pengaruh Leverage Dan Profitabilitas Terhadap Nilai Perusahaan (Studi Pada Perusahaan Sektor Manufaktur Food And Beverage Yang Terdaftar Di Bursa Efek Indonesia). Jurnal Sains Manajemen \& Akuntansi, X(1).

Yanti, I. G. A. D. N., \& Darmayanti, N. P. A. (2019). Pengaruh Profitabilitas, Ukuran Perusahaan, Struktur Modal, Dan Likuiditas Terhadap Nilai Perusahaan Makanan Dan Minuman. E-Jurnal Manajemen, 8(4), 2297-2324. Https://Doi.Org/Https://Doi.Org/10.24843/Ejmunud.2019.V8.I4.P15 
